


\section{The United States in the Indo-Pacific}

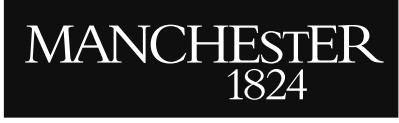

Manchester University Press 
Oliver Turner and Inderjeet Parmar - 9781526135025 Downloaded from manchesterhive.com at 04/26/2023 ๑8: 02 :54AM 


\title{
The United States in the Indo-Pacific
}

\section{Obama's legacy and the Trump transition}

\author{
Edited by \\ Oliver Turner and Inderjeet Parmar
}

Manchester University Press 
Copyright () Manchester University Press 2020

While copyright in the volume as a whole is vested in Manchester University Press, copyright in individual chapters belongs to their respective authors.

This electronic version has been made freely available under a Creative (CC-BY-NC-ND) licence, which permits non-commercial use, distribution and reproduction provided the editor(s), chapter author(s) and Manchester University Press are fully cited and no modifications or adaptations are made. Details of the licence can be viewed at https:// creativecommons.org/licenses/by-nc-nd/4.0/

Published by Manchester University Press

Altrincham Street, Manchester M1 7JA

www.manchesteruniversitypress.co.uk

British Library Cataloguing-in-Publication Data

A catalogue record for this book is available from the British Library

ISBN 9781526135018 hardback

ISBN 9781526135032 paperback

ISBN 9781526135025 open access

First published 2020

The publisher has no responsibility for the persistence or accuracy of URLS for any external or third-party internet websites referred to in this book, and does not guarantee that any content on such websites is, or will remain, accurate or appropriate.

Cover image: @ Rob Pinney

Typeset by Newgen Publishing UK 